\title{
Challenges in the diagnosis, treatment and management of asthma during COVID-19 pandemic
}

Rohozneanu Oana Elena $a^{1, \#}$, Crișan-Dabija Radu Adrian ${ }^{1,2}$, Vicol Cristina ${ }^{1, \#, *}$, Țurcanu Adina Magdalena ${ }^{1,2}$, Trofor Antigona Carmen ${ }^{1,2}$, Bucúlei loana ${ }^{1, \#}$

${ }^{1}$ Pneumology Department, University of Medicine and Pharmacy "Grigore T. Popa", lasi, Romania

${ }^{2}$ Clinic of Pulmonary Diseases, lasi, Romania

Abstract

\section{English:}

People over the age of 65 and those suffering from chronic diseases, such as asthma, are part of the risk group for severe acute respiratory syndrome-COV-2 (SARS-CoV-2) infection. In the past, a connection between viral infections and asthma has been presented. Patients with asthma appear to be at risk of contracting viral infections, and also viruses can cause asthma exacerbations. Another concern during this period was about the chronic administration of corticosteroids in asthmatic patients, because of the consideration that corticosteroid therapy would decrease the immunity of these patients, thus increasing the risk of infections, including the infection with SARS-CoV-2. Thus, several questions have emerged about the role of corticosteroid therapy in the development of COVID-19 in patients undergoing corticosteroid treatment. Most guidelines recommend continuing the administration of chronic treatment to this category of patients. At the same time, the health system had to adapt to the situation caused by the COVID-19 pandemic and deviate from the standard methods of managing most chronic diseases and these changes had an impact on these category of patients.

Keywords

COVID-19 $\cdot$ asthma $\cdot$ viral infections $\cdot$ corticotherapy

\section{Provocări în diagnosticul, tratamentul și managementul astmului bronșic în pandemia COVID-19}

Rezumat

\begin{abstract}
Romanian:
Persoanele cu vârsta peste 65 de ani și cele care suferă de boli cronice, precum astmul bronșic, fac parte din grupul de risc pentru infecția cu SARS-CoV-2. În trecut, s-a demonstrat existența unei conexiuni între infecțiile virale și astm. Pacienții cu astm par să aibă un risc crescut de a contracta infecții virale, iar virusurile pot provoca exacerbări ale astmului. O altă preocupare în această perioadă a fost reprezentată de administrarea cronică a corticosteroizilor la pacienții astmatici, datorită ideii că aceștia ar scade imunitatea acestor pacienți crescând astfel riscul de infecții, inclusiv cu virusul SARS-COV-2. Au apărut astfel mai multe întrebări cu privire la rolul corticoterapiei în dezvoltarea COVID-19 la pacientii aflați sub tratament cu corticosteroizi, iar majoritatea ghidurilor recomandă continuarea administrării tratamentului cronic la această categorie de pacienți. Totodată sistemul de sănătate a trebuit să se adapteze la situația cauzată de pandemia COVID-19 și să se abată de la metodele standard de gestionare a majorității bolilor cronice, iar aceste modificări au avut impact asupra acestei categorii de pacienți.
\end{abstract}

Cuvinte-cheie

COVID-19 • astmul bronșic • infecții virale $\bullet$ corticoterapie

*Corresponding author: Vicol Cristina, Str. Dr. I. Cihac, nr. 30, Iaşi, Cod 700115, România.

E-mail: criss_mydoc@yahoo.com

\#PhD Student

ว Open Access. ๑) 2020 Rohozneanu et al., published by Sciendo

(c) Br-Nc-ND This work is licensed under the Creative Commons Attribution-NonCommercial-NoDerivs 4.0 License. 


\section{Introduction}

COVID-19 is an infectious disease caused by the SARSCoV-2 virus that has a high potential for spreading and infecting humans. The virus was first identified in humans on December 2019 in Wuhan, China. Coronaviruses are a family of single-stranded RNA viruses that are transmitted to humans primarily through flügge droplets or fomites. Alphacoronaviruses, HCoV-NL63 and HCoV-229E, and betacoronaviruses, HCoV-OC43, HCoV-HKU1, severe acute respiratory syndrome-COV (SARS-CoV) and Middle Eastern respiratory syndrome (MERS-CoV) were the six known human coronaviruses until the outbreak of the pandemic in December 2019. The SARS-CoV-2 virus has not been found in humans until the outbreak and is a beta-CoV that infects both humans and animals by zoonotic transmission. Bats are considered to be the source of SARS-CoV and SARSCoV-2 based on sequence similarity to bat CoVs [1]. The most common manifestations of the disease are found to be respiratory manifestations, though patients diagnosed with COVID-19 may also have cardiovascular, hepatobiliary, gastrointestinal, renal, neurological, musculocutaneous, haematological and gynaecological manifestations. A dry cough is a common symptom of COVID-19 infection, which presents in up to $68 \%$ of patients [2]. The least common symptoms, $5 \%$ or less, are sore throat and sputum production [3]. When dyspnoea is present, it signals an unfavourable evolution, and it is a predictive for or confirms the subsequent need for hospitalisation in intensive care units [1]. SARSCoV-2 infected Chinese patients who were hospitalised were characterized by an abnormal chest computed tomography (CT). The most common abnormalities on the CT images were ground glass opacities ( $56 \%$ ), followed by consolidation and interstitial abnormalities [4]. The clinical course of this infectious disease ranges from asymptomatic infection to severe acute respiratory infection (SARI) and death. According to the Centers for Disease Control and Prevention (CDC), people over the age of 65 and those with chronic diseases are the major risk group for COVID-19. Moderate to severe asthma is one of the chronic diseases [5] along with hypertension, chronic obstructive pulmonary disease and diabetes [6]. According to the report of World Health Organization's (WHO) on 21 September 2020, more than 30.6 million cases of COVID-19 and 950,000 deaths have been reported globally. Between 13 and 20 September 2020, $1,998,897$ new cases and 36,764 deaths were reported globally. In Romania, 9,164 new cases (a total of 111,550) and 275 deaths (a total of 4,402 ) were reported during the same period of time [7].

Advances in asthma research have led to the development of evidence-based guidelines and a major paradigm shift towards control-based asthma management. Several guidelines have been developed and published by the National Heart, Lung, and Blood Institute (NHLBI), the Global Initiative for Asthma (GINA) and the British Thoracic Society (STD) [8]. According to the Global Strategy for Asthma Management and Prevention updated and published this year, asthma is a chronic, heterogeneous disease characterized by chronic inflammation of the airways. The history of respiratory symptoms (such as wheezing, dyspnoea, chest tightness and cough) that vary in duration of time and intensity, along with the variable expired airflow limitation, are two defining characteristics for the diagnosis of asthma [9].

The goal of the asthma treatment is to achieve better control of the disease, which involves managing the symptoms and reducing the impact they have on the quality of life of the patient and simultaneously reducing the risk of exacerbations to avoid disease progression. Asthma treatment is a stepby-step treatment, and the main medication used is antiinflammatory drugs and bronchodilators. The choice and the modification of the treatment are based on the periodic evaluation of symptoms control, risk factors, comorbidities, side effects and patient contentment by means of shared decisions. Severe asthma is defined as the need to use higher-level medications to control symptoms or is defined as asthma that is not controlled despite maximal treatment [10]. Exacerbations are acute or subacute episodes of increased intensity of the asthma symptoms characterised by progressive increase of dyspnoea, coughing, wheezing, or chest tightness and decreased lung function and they are part of the natural evolution of asthma $[9,11]$. Because of major cause of disease morbidity, rising healthcare costs and, in some patients, more rapid progressive loss of lung function, asthma exacerbations should be avoided as much as possible and treated immediately with inhaled corticosteroids (ICS) or combination of ICS and long-acting beta2-agonists (LABA). Sometimes standard treatment will have no effect, so it is important to identify high-risk patients and establish a management plan to improve disease control and quality of life of the patients [11].

Managing asthma and especially severe asthma during the COVID-19 pandemic is a daunting task, especially because of the changes that are taking place in hospital settings and the existing concerns associated with the administration of inhaled or oral corticosteroids to asthmatic patients. At the same time, patients are afraid to seek emergency care due to the current uncertainties, and moreover their addressability is lower during this period. So probably we will have to deal with more presentations in emergency departments in the 
near future due to exacerbations of asthma and severe asthma.

\section{Changes in health facilities}

Due to the unprecedented demand of hospital services, it is necessary for the health system to adapt to the situation caused by the COVID-19 pandemic and to modify or deviate from standard management methods of most chronic diseases. Of course, these changes will bring both advantages and disadvantages to the patients. It is necessary to increase the number of beds and the capacity of intensive care units, and these have already been achieved by cancelling elective activities, using operating rooms for other purposes and commissioning use of private facilities [12].

In the future, the discharge of existing patients will be carried out and will be supported by all. Further, the activity of specialised outpatient clinics will be reduced in order to minimise the contact of patients with medical staff and other patients and thus reducing the risk of infection with SARSCoV-2 [13].

Currently, new methods are being implemented to allow patients to get in touch with doctors without any need for face-to-face meetings. One such method is telemedicine, which was used before the COVID-19 crisis, but it seems that the obstacles encountered in the past, such as cybersecurity issues and patient privacy, have been overcome easily now [14].

Based on the rapid changes in medical facilities due to the COVID-19 pandemic, Isaac and colleagues present the clinical strategies used in the Cardiac Surgery Practice and the future prospects they have identified during their work. Some of the strategies implemented were the use of telemedicine, reducing the number of operations performed per day, redeploying staff, including resident physicians in specific teams and creating intensive care units in operating rooms. The use of telemedicine aimed to minimise the risk of nosocomial COVID-19 infections in patients/providers and also to minimise the staff and support services requirements. The objective of reducing the number of cases was to minimise the risk of COVID-19 nosocomial infections, limit the consumption of protective equipment, vital equipment and treatments, preserve intensive care units, maintain an open space to supplement intensive care units and make providers available to care for patients with COVID-19 [15].

In May 2020, the Romanian Ministry of Health approved the Plan of measures for preparing hospitals to deal with the COVID-19 outbreak, the List of hospitals that provide medical care for patients tested positive for SARS-CoV-2 in phase I and phase II and the List of support hospitals for patients suspected or confirmed to have been infected with the novel
SARS-CoV-2. The plan of measures for the preparation of hospitals is a framework document that establishes the steps to be followed by the management of healthcare units and the measures to be implemented for the isolation and treatment of positive cases. The insurance of medical care for patients tested positive for SARS-CoV-2 virus was achieved through the phased involvement of hospitals. In phase I, the hospitals that provided medical care to patients tested positive for SARS-CoV-2 virus were the infectious diseases hospitals organised into pavilion model. When the capacity of these hospitals was exceeded in terms of the number of hospitalised patients, phase II plan was implemented. Phase II involved hospitalisation of these patients in pulmonology hospitals organised into pavilion model and also in support hospitals where chronic patients are gradually discharged so that they were available additionally to help hospitals that are working at full capacity. Patients with chronic diseases were taken over by other referral centres [16].

Phase II hospitals are hospitals dedicated totally or partially to the treatment of COVID-19 patients, which depend on the possibility of creating separate circuits. Patients with mild and moderate forms are hospitalised in these hospitals, and further severe cases are also hospitalised if intensive care units or compartments are equipped with mechanical ventilators. These hospitals have the possibility to acquire ventilators from non-COVID-19 hospitals and to get/ delegate necessary medical staff including infectious disease specialists for interdisciplinary consultations from other public and private health units. Support hospitals discharge/transfer all hospitalised patients to other hospitals and expected to ensure the treatment of associated pathologies of the patients suspected or confirmed COVID-19 positive with mild or moderate forms, as well as severe forms if their intensive care units or compartments are equipped with mechanical ventilators. Also, support hospitals need to provide separate circuits for suspected COVID-19 patients until they are confirmed positive; they can borrow ventilators from nonCOVID-19 hospitals, they can detach/delegate necessary medical staff from other health facilities including an infectious disease specialist for interdisciplinary consultations [17].

\section{Viral infections and asthma}

The relationship between respiratory viral infections and asthma has long been known, but not well understood. Viral infections at an early stage can be a risk factor for the development of asthma. Exacerbations can also be caused by viral infections and they can influence the evolution of asthma [18]. The study of Lu et al. that attempted to identify predictors of bronchial asthma showed that the risk of a diagnosis of asthma at age 6 was determined by severe Respiratory 
Syncytial Virus (RVS)-induced bronchiolitis, along with a family history of asthma that highlights the interaction with atopy [19]. Viral infection is strongly correlated to early childhood wheezing and the subsequent development of asthma. The association between viral infections and asthma exacerbation in adolescents and adults diagnosed with asthma is also particularly strong. Acute exacerbations in asthma are the main cause of hospitalisation and deaths, and because of this reason more attention has been paid to the factors responsible for their occurrence [18]. The most commonly incriminated viruses are rhinoviruses (RV), especially subtypes $A$ and $C$ [20]. Hospitalisations caused by asthma exacerbations are correlated with a seasonal increase in rhinovirus infections in the fall, from September to December, and again in the spring [21]. Other respiratory viruses can also cause exacerbations. Human metapneumo virus, influenza virus, parainfluenza, adenovirus, coronavirus and bocavirus were all detected in asthma exacerbations, but with a lower frequency [22]. RV, the common cold virus, is clearly the most common trigger for exacerbations; covering up to $76 \%$ of exacerbations in children with wheezing and up to $83 \%$ of exacerbations in adult asthma [23]. Because asthma is also an inherited disease and with heredity estimates in twins over $50 \%$ based on studies, genetics is an important tool for understanding the mechanisms of this disease. Knowledge about the genetics of asthma has grown rapidly in recent years through methodological advances that allow so-called genome-wide association studies (GWAS), in which millions of genetic variants covering the entire genome can be tested without a prior hypothesis about the underlying mechanisms [23]. The first asthma locus discovered in GWAS was the locus of chromosome 17q21 and is especially associated with childhood-onset asthma and asthma with severe exacerbations [24]. At the same time, the 17q21 locus is strongly associated with an increased risk of early wheezing episodes triggered by viruses, including rhinoviruses. Children with early wheezing episodes triggered by viruses have a much higher risk of developing asthma later in life if they have $17 q 21$ risk variants [23]. CDR3 is a gene associated with an increased risk of asthma, and moreover, studies have shown that this gene functions as a receptor for rhinovirus $C$ and it is very well expressed in differentiated bronchial epithelial cells [25].

In the mechanism of triggering asthma exacerbations, the airway epithelium plays an important role because it acts as a barrier between the internal and the external environment. The external environment contains potentially harmful gases, agents and pathogens, including viruses. There are molecular patterns associated with pathogens (PAMPs), such as viral or bacterial nucleic acids, fungal products and bacterial endotoxins, such as lipopolysaccharides (LPS), that interact with airway epithelium because they are recognised by pattern recognition receptors (PRRs) encoded in the innate germ line in the cell surface and cytoplasm and can determine a strong immune response $[26,27]$. The presence of RNA viruses at this level is detected by PRR, such as Toll-like receptors (TLRs). TLR3, for example, is expressed in the intracellular endosomes of bronchial epithelial cells and responds to the presence of double-stranded RNA, which is produced during replication of these viruses, causing production of inflammatory cytokines [28]. During viral infections, the airways produce cytokines and chemokines, and they have different roles in innate and adaptive immunity. For example, IL-6 is a proinflammatory cytokine that modulates the activity of lung neutrophils, monocytes and T cells. Increased secretion of IL-6 can cause excessive inflammation and injury. But, the absence of IL- 6 in influenza infection increases viral replication and reduces the activity of antiviral $\mathrm{T}$ cells.

A four-year study (1990-1995) that included defined populations that are representative of Houston residents revealed that influenza virus infection was most commonly associated with hospitalisation for acute respiratory conditions, including asthma [29].

With the detection of the new A (H1N1) pdm09 virus in the spring of 2009 when a flu pandemic was triggered, numerous epidemiological studies have detected asthma as a common comorbid condition in patients infected with the virus. The attention paid to the flu virus is justified by the morbidity and mortality that this virus causes in annual epidemics [30]. Kloepfer et al. [31] showed by conducting a study on H1N1 infections during the peak viral season that children with asthma had an increased susceptibility to viral infection A (H1N1) pdm09. A total of 346 viral infections were detected in the weekly collection of nasal samples from 161 children (95 with asthma and 66 without asthma). About $34 \%$ of children were infected with the $A(H 1 N 1)$ pdm09 virus during the study period, and the incidence of viral A (H1N1) pdm09 infection was significantly higher in children with asthma (41\%) than in children without asthma (24\%), while the incidences of RV and other viral infections ( $47 \%$ vs. $41 \%$ ) were similar [31]. Once the influenza A virus reaches the airways, the airway epithelial cells and other cells, including peripheral blood basophils, will induce the production of interleukin 1 beta (IL-1 $\beta$ ), IL-6, IL-8, tumour necrosis factor-alpha (TNF- $\alpha$ ), histamine, protease, interferon alpha (IFN- $\alpha$ ) and interferon gamma (IFN-y) [32]. Thus, by stimulating airway inflammation and affecting the barrier function, these cytokines, monokines and proinflammatory substances can cause exacerbation of asthma [30].

Similar to the 2009 flu pandemic, the 2017-2018 flu seasons also attracted a lot of attention due to the high mortality associated with this $\mathrm{H} 3 \mathrm{~N} 2$ virus strain compared to previous seasonal strains [33].

During the swine flu pandemic, the severity of the disease was also indicated by the necessity to admit patients to 
intensive care units and the deaths caused by it. Regarding the association of influenza with asthma, a number of reports suggested that asthmatics had less severe influenza morbidity compared with non-asthmatics [34,35] with a low risk of admission to intensive care units and death [33]. Analysis of data systematically obtained on 1,520 patients admitted to 75 UK hospitals between May 2009 and January 2010 infected with $\mathrm{pH} 1 \mathrm{~N} 1$ also showed that asthmatics have a reduced risk of severe influenza [36]. At the same time, the receptivity of asthmatics to early antiviral treatment and corticosteroid therapy was higher [37]. However, corticosteroid treatment was also associated with an increased risk of mortality, nosocomial infections and mechanical ventilation, and prolonged hospitalisation in intensive care units [38]. Because asthmatics have a transient immunosuppressive state following steroid treatment, they may be at increased risk of pH1N1 infection [33].

The influence of corticosteroid treatment on the risk of SARS-CoV-2 infection

There are doubts and discussions about whether to continue or stop corticosteroids treatments because of the immunosuppression they may cause. Thus, multiple questions arise about the role that corticosteroids have in the development of COVID-19 in patients undergoing chronic corticosteroid treatment. Exogenous glucocorticoids (GC) are thought to suppress immunity. Because of this reason, the WHO recommended at the beginning of the COVID-19 pandemic that corticosteroids should not be used outside of clinical trials and should be used only under strict specific conditions [39], fearing that they could promote viral spread by limiting the first line of defence (innate immunity) which is very sensitive to the action of glucocorticosteroids [40]. However, patients with chronic obstructive pulmonary disease, asthma or rheumatic disorders who received corticotherapy were not at increased risk of developing severe forms of COVID-19 [41-43].

As far as inhaled corticosteroids concerned, they are used worldwide alone or in combination with bronchodilators, both for the treatment of asthma and chronic obstructive pulmonary disease (COPD). Some questions have been raised against their use as a chronic treatment during the COVID-19 pandemic due to the influence that steroids appear to have on the risk of viral infections and exacerbation rates. Data from the literature show a higher prevalence of pneumonia and changes in the lung microbiome of patients with COPD [44]. But, things are not clear in the case of asthma, but at least one observational study has shown an increased risk of pneumonia or lower respiratory infection [45]. It is known that ICS reduce the rate of exacerbations in both asthma and COPD, and by stopping or reducing their administration due to fears of immunosuppression and of imminent infection with the new SARS-CoV-2, the risk of exacerbation in this category of patients will significantly increase [44]. Regarding the causes of exacerbations, about $40--60 \%$ of COPD and up to $80 \%$ of asthma exacerbations are caused by viral infections including common coronavirus infections [46].

Steroids were commonly used during the 2002-2004 outbreak of severe acute respiratory syndrome coronavirus (SARSCoV-1) in addition to other drugs, and as the COVID-19 pandemic progresses, more evidences are obtained on the potential role of corticosteroids in the management of COVID-19 cases, which are currently being administered in many centres for the treatment of COVID-19 disease [47]. The Society of Infectious Diseases of America (IDSA) initially published a guideline that did not recommend the use of corticosteroids in COVID-19 because existing data from previous experience of treating coronavirus infections with corticosteroids have not shown any benefits [48]. However, the guideline was subsequently updated based on the results of the RECOVERY study and recommended the use of glucocorticoids (preferably dexamethasone, alternatively methylprednisolone or prednisone) in hospitalised patients with severe COVID-19. But the administration of steroid therapy to patients without hypoxemia is still discouraged [47]. The Chinese Thoracic Society (CTS) has provided a consensus on the use of steroids in the treatment of COVID-19, making the following recommendations: it is necessary to study the relationship between the risks and benefits of steroid use; in patients with critical illness, careful administration of steroids is recommended; special attention should be paid to patients with hypoxemia caused by comorbidities or to patients who use steroids regularly for other associated chronic diseases; the dose administered should be small to moderate ( $\leq 0.5-1 \mathrm{mg} / \mathrm{kg} /$ day methylprednisolone or equivalent) and the duration of administration should be short ( $\leq 7$ days) [49].

\section{Recommendations for patients with asthma}

Managing patients with asthma during COVID-19 pandemic is a challenge, because there are insufficient data on how COVID-19 disease affects patients with asthma. Regarding the administration of inhaled or oral corticosteroids to patients diagnosed with asthma, The Global Asthma Initiative (GINA) recommends continuing the administration of all inhaled medicines, including inhaled corticosteroids, and further patients may follow a short course of oral corticosteroids as recommended by the attending physician in case of exacerbation, thus preventing serious consequences [50]. American Lung Association advises patients to continue 
their use of inhaled corticosteroids or intranasal steroids and not to discontinue treatment because there is probably no risk of weakening the immune system by using this type of treatments. It is also recommended to contact the attending physician in case of exacerbation to determine the appropriate therapeutic conduct [51]. The National Institute of Health and Care Excellence (NICE) recommends that patients should continue to take oral and inhaled medications, including corticosteroids, according to their individual treatment plan, including patients suspected or confirmed with COVID-19. Further, for patients with symptoms of COVID-19, the guideline recommends that patients do not begin short-term treatment with oral corticosteroids and/or antibiotics. For patients using non-invasive ventilation at home, they are recommended to take appropriate precautions, such as using the equipment in a well-ventilated room and in the absence of family members or any one, because these type of procedures can potentially cause infection with SARS-CoV-2 by generating aerosols [52]. There are currently new therapies that can be used to treat asthma, such as biologic therapies that offer a more promising and personalised treatment option in severe asthma, but their safety needs further research during the SARS-CoV-2 pandemic [53].

The Global Asthma Initiative (GINA) recommends the use of biologic therapies in patients with severe asthma who qualify for their use in order to limit the use of oral corticosteroids [50]. European Respiratory Society (ERS) and European Lung Foundation (ELF) suggest that anti-IL5 should not increase the risk of COVID-19 and further administration could theoretically reduce the risk of asthma attack caused by SARS-CoV-2 infection [54].

The Pneumology Commission of Romanian Ministry of Health issued recommendations about the approach of respiratory diseases during the Covid-19 pandemic, which included recommendations for the management of asthma. The Commission recommendations are to continue administration of chronic inhaled medicines (including inhaled corticosteroids) and biologic therapies as recommended by the attending physician to this category of patients. But in case of an asthma attack, the advice is to use inhaled short-acting beta-2-adrenergics (salbutamol). Exacerbations should be managed by administrating a short course (up to 7 days) of oral corticosteroids and continuing administration of inhaled corticosteroids (according to the instructions received after the periodic evaluation or telephonic recommendation of the attending physician). Control spirometry should be avoided or if necessary this investigation will be carried out considering all the measures to prevent the spread of SARS-CoV-2. Nebulisation of bronchodilators should be also avoided (due to the increased risk of coronavirus infection in other patients and medical staff); the use of spacers is preferred for the administration of bronchodilators during emergencies in the event of a severe asthma attack. The use of nasal corticosteroids by patients diagnosed with allergic rhinitis should be continued as prescribed by the attending physician [55].

\section{Conclusions}

The asthma control during the COVID-19 pandemic is absolutely important for protecting asthma patients against infection with SARS-CoV-2 and development of severe symptoms. Viral infections are important triggers of asthma exacerbations and data from the existing literature show people suffering from asthma are at risk of contracting viral infections. Guidelines and experts advise towards continuance of steroids as treatment for asthma even during this difficult time (either alone or combined) and also biological agents. Despite the challenges caused by COVID-19 pandemic all around the world, the healthcare system and the patients need to adapt the best and effective way as far as possible. Changes are being made in the way hospitals are organised (there are hospitals treating only patients with suspected or confirmed COVID-19), but authorities must find ways to help and treat patients suffering from chronic diseases (such as asthma) taking into account of their high risk for infection with SARS-CoV-2 and exacerbations.

Future studies are required to obtain a greater understanding of the impact of underlying asthma on COVID-19, the disease outcome and to comprehend why patients with asthma are at greater risk of contracting the infection with SARS-CoV-2. Only time and the acquired knowledge during scientific progress will help us understand these interactions in a better way and protect people from high-risk category, such as people with chronic respiratory diseases, effectively.

\section{References}

1. Aishwarya G, Corbin P, Zahra Q, Stephanie T, Daniel F, Gautam G, et al. A comprehensive review of manifestations of novel coronaviruses in the context of deadly COVID-19 global pandemic. The American Journal of the Medical Sciences. 2020;360(1): 5-34.

2. Wang D, Hu B, Hu C, Zhu F, Liu X, Zhang J, et al. Clinical characteristics of 138 hospitalized patients with 2019 novel coronavirus-infected pneumonia in Wuhan, China. JAMA. 2020;323(11): 1061-1069.

3. Guan WJ, Ni ZY, Hu Y, Liang W-H, Ou C-Q, He J-X, et al. Clinical characteristics of coronavirus disease 2019 in China. The New England Journal of Medicine. 2020;382:1708-1720.

4. Huang C, Wang Y, Li X, Ren L, Zhao J, Hu Y, et al. Clinical features of patients infected with 2019 novel coronavirus in Wuhan, China. Lancet. 2020;395(10223): 497-506. 
5. Sarioğlu N. Asthma and COVID-19: what do we know? Tuberk Toraks. 2020;68(2): 141-147.

6. Bolin W, Ruobao L, Zhong L, Yan H. Does comorbidity increase the risk of patients with COVID-19: evidence from meta-analysis. Aging. 2020;12(7): 6049-6057.

7. World Health Organization. Coronavirus disease (COVID-19). Available from: https://www.who.int/docs/default-source/coronaviruse/situation-reports/20200921-weekly-epi-update-6.pdf?sfvrsn=d9cf9496_6 [Accessed 19th September 2020].

8. Reddy AP, Gupta MR. Management of asthma: the current US and European guidelines. Advances in Experimental Medicine and Biology. 2014;795: 81-103.

9. Global Initiative for Asthma. Global Strategy for Asthma Management and Prevention. Updated 2020.

10. Papi A, Brightling C, Pedersen SE, Reddel HK. Asthma. Lancet. 2018;391: 783-800.

11. Castillo JR, Peters SP, Busse WW. Asthma exacerbations: pathogenesis, prevention, and treatment. The Journal of Allergy and Clinical Immunology. 2017;5(4): 918-927.

12. NHS England. Next steps on NHS response to COVID-19: Letter from Sir Simon Stevens and Amanda Pritchard. Available from: https://www.england.nhs.uk/coronavirus/wp-content/uploads/sites/52/2020/03/20200317-NHS-COVID-letter-FINAL.pdf [17th March 2020]

13. Willan J, King AJ, Jeffery K, Bienz N. Challenges for NHS hospitals during covid-19 epidemic Healthcare workers need comprehensive support as every aspect of care is reorganised. BMJ. 2020;368: m1117.

14. Sulindro A, Nguyen Q, Provenzano Da, Gharibo C, Soin A, Kohan $\mathrm{L}$, et al. The technological impact of COVID-19 on the future of education and health care delivery. Pain Physician. 2020;23: S367-S380.

15. George I, Salna M, Kobsa S, Deroo S, Kriegel J, Kriegel D, et al. The rapid transformation of cardiac surgery practice in the coronavirus disease 2019 (COVID-19) pandemic: insights and clinical strategies from a center at the epicenter. The Annals of Thoracic Surgery. 2020;110: 1108-1118.

16. Order of the Minister of Health no.753/2020 for the modification of the order of the minister of health no.555/2020 regarding the approval of the plan of measures for the preparation of hospitals in the context of the covid-19 coronavirus epidemic. Available from: https://www.cnscbt.ro/index. php/lex/1752-ordinul-nr-753-2020-pentru-modificarea-ordinului-ministrului-sanatatii-nr-555-2020-privind-aprobarea-planului-de-masuri-pentru-pregatirea-spitalelor-in-contextul-epidemiei-de-coronavirus-covid-19-a-li/file [Accessed 20th September 2020].

17. Order of the Minister of Health no. 555 of April 3, 2020 on the approval of the Plan of measures for the preparation of hospitals in the context of the coronavirus epidemic COVID-19, of the List of hospitals providing medical care to patients tested positive for SARS-CoV-2 virus in phase I and phase II and a List of support hospitals for patients tested positive or suspected of having the SARS-CoV-2 virus. Available from: http://www.cnas. ro/cjastm/media/postFiles/Ordin\%20555_2020.pdf [Accessed 20th September 2020].

18. Wark PAB, Ramsahai JM, Pathinayake P, Malik B, Bartlett NW. Respiratory viruses and asthma. Seminars in Respiratory and Critical Care Medicine. 2018;39: 45-55.

19. Lu S, Hartert TV, Everard ML, Giezek H, Nelsen LM, Mehta A, et al. Predictors of asthma following severe respiratory syncytial virus (RSV) bronchiolitis in early childhood. Pediatric Pulmonology. 2016;51(12): 1382-1392.

20. Lee WM, Lemanske RF Jr, Evans MD, Vang F, Pappas T, Gangnon R, et al. Human rhinovirus species and season of infection determine illness severity. American Journal of Respiratory and Critical Care Medicine. 2012;186(9): 886-891.

21. Johnston NW, Johnston SL, Duncan J, Greene JM, Kebadze T, Keith PK, et al. The September epidemic of asthma exacerbations in children: a search for etiology. The Journal of Allergy and Clinical Immunology. 2005;115(1): 132-138.

22. Jartti T, Gern JE. Role of viral infections in the development and exacerbation of asthma in children. The Journal of Allergy and Clinical Immunology. 2017;140(4): 895-906.

23. Jartti T, Bønnelykke K, Elenius V, Feleszko W. Role of viruses in asthma. Seminars in Immunopathology. 2020;42: 61-74.

24. Stein MM, Thompson EE, Schoettler N, Helling BA, Magnaye $\mathrm{KM}$, Stanhope $\mathrm{C}$, et al. A decade of research on the 17q12-21 asthma locus: piecing together the puzzle. The Journal of Allergy and Clinical Immunology. 2018;142(3): 749-764.

25. Bochkov YA, Watters K, Ashraf S, Griggs TF, Devries MK, Jackson DJ, et al. Cadherin-related family member 3, a childhood asthma susceptibility gene product, mediates rhinovirus $\mathrm{C}$ binding and replication. Proceedings of the National Academy of Sciences of the United States of America. 2015;112(17): 5485-5490.

26. Kumar $\mathrm{H}$, Kawai $\mathrm{T}$, Akira $\mathrm{S}$. Pathogen recognition by the innate immune system. International Reviews of Immunology. 2011;30(1): 16-34.

27. Kumagai $Y$, Takeuchi $O$, Akira S. Pathogen recognition by innate receptors. Journal of Infection and Chemotherapy. 2008;14(2): 86-92.

28. Bowie $A G$, Haga IR. The role of toll-like receptors in the host response to viruses. Molecular Immunology. 2005;42(08): 859-867.

29. Glezen WP, Greenberg SB, Atmar RL, Piedra PA, Couch RB Impact of respiratory virus infections on persons with chronic underlying conditions. JAMA. 2000;283: 499-505.

30. Masatsugu O, Yuichi A, Takenori T, Tetsutaro S. Influenza $\mathrm{A}(\mathrm{H} 1 \mathrm{~N} 1) \mathrm{pdm} 09$ virus and asthma. Frontiers in Microbiology. 2013;4: 307-312.

31. Kloepfer KM, Olenec JP, Lee WM, Liu G, Vrtis RF, Roberg KA, et al. Increased H1N1 infection rate in children with asthma. 
American Journal of Respiratory and Critical Care Medicine. 2012;185: 1275-1279.

32. Yamaya M. Virus infectioninduced bronchial asthma exacerbation. Pulmonary Medicine. 2012;2012: 834826.

33. Veerapandian R, Snyder JD, Samarasinghe AE. Influenza in asthmatics: for better or for worse? Frontiers in Immunology. 2018;9: 1843.

34. Kerkhove V, Vandemaele KA, Shinde V, Jaramillo-Gutierrez G, Koukounari A, Donnelly CA, et al. Risk factors for severe outcomes following 2009 influenza A (H1N1) infection: a global pooled analysis. PLoS Medicine. 2011;8: e1001053.

35. Nguyen-Van-Tam JS, Openshaw PJ, Hashim A, Gadd EM, Lim WS, Semple MG, et al. Risk factors for hospitalisation and poor outcome with pandemic A/H1N1 influenza: United Kingdom first wave (May-September 2009). Thorax. 2010;65: 645-651.

36. Myles PR, Semple MG, Lim WS, Openshaw JM, Gadd EM, Read RC, et al. Predictors of clinical outcome in a national hospitalised cohort across both waves of the influenza A/H1N1 pandemic 2009-2010 in the UK. Thorax. 2012;67: 709-717.

37. Brun-Buisson C, Richard JC, Mercat A, Thiébaut CM, Brochard L; REVA-SRLF A/H1N1v 2009 registry group. Early corticosteroids in severe influenza $\mathrm{A} / \mathrm{H} 1 \mathrm{~N} 1$ pneumonia and acute respiratory distress syndrome. American Journal of Respiratory and Critical Care Medicine. 2011;183: 1200-12006.

38. Zhang Y, Sun WJ, Svendsen ER, Tang S, et al. Do corticosteroids reduce the mortality of influenza $A(\mathrm{H} 1 \mathrm{~N} 1)$ infection? A meta-analysis. Critical Care. 2015;19: 46.

39. World Health Organization (WHO), 2020. Available from: https:// www.who.int/emergencies/diseases/novel-coronavirus-2019?gclid=CjwKCAjwwab7BRBAEiwAapqpTKuKNANFo8ob1Vu-a2jzaJWpFm8G1KhxdntVck5w4wdZM-7w7gpwXxoC-KIQ AvD_BwE [Accessed 19th September 2020].

40. Isidori AM, Arnaldi G, Boscaro M, Falomi A, Giordano C, Giordano C, et al. COVID-19 infection and glucocorticoids: update from the Italian Society of Endocrinology Expert Opinion on steroid replacement in adrenal insufciency. Journal of Endocrinological Investigation. 2020;43: 1141-1147.

41. Baud D, Qi X, Nielsen-Saines K, Musso D, Pomar L, Favre G. Real estimates of mortality following COVID-19 infection. The Lancet Infectious Diseases. 2020;20(7): P773.

42. Figueroa-Parra G, Aguirre-Garcia GM, Gamboa-Alonso CM, Camacho-Ortiz A, Galarza-Delgado. Are my patients with rheumatic diseases at higher risk of COVID-19? Annals of the Rheumatic Diseases. 2020;79: 839-840.

43. Halpin DMG, Faner R, Sibila O, Badia JR, Agusti A. Do chronic respiratory diseases or their treatment affect the risk of SARSCoV-2 infection? The Lancet Respiratory Medicine. 2020;8(5): P436-P438.
44. Halpin DMG, Singh D, Hadfield RM. Inhaled corticosteroids and COVID-19: a systematic review and clinical perspective. European Respiratory Journal. 2020;55: 2001009.

45. McKeever T, Harrison TW, Hubbard R, Shaw D. Inhaled corticosteroids and the risk of pneumonia in people with asthma: a case-control study. Chest. 2013;144: 1788-1794.

46. Johnston SL. Overview of virus-induced airway disease. Proceedings of the American Thoracic Society. 2005;2: 150-156.

47. Mattos-Silvaa P, Felixa NS, Silva PL, Robba C, Battaglini D, Pelosi P. Pros and cons of corticosteroid therapy for COVID-19 patients. Respiratory Physiology \& Neurobiology. 2020;280: 103492.

48. Bhimraj A, Morgan L, Shumaker AH, Lavergne V, Baden L, Cheng, VC-C, et al. Infectious Diseases Society of America Guidelines on the Treatment and Management of Patients With COVID-19; 2020. Available form: https://www.idsociety.org/practice-guideline/covid-19-guideline-treatment-and-management/ [Accessed 18th Septembre 2020].

49. Zhang S, Li D, Chen HZ, Zheng D, Zhou Y, Chen B, et al. Dynamic inflammatory response in a critically ill COVID-19 patient treated with corticosteroids. Journal of Zhejiang University (Medical Science). 2020;49(2): 220-226.

50. Global Initiative for Asthma (GINA), Recommendations for inhaled asthma controller medications, Available from: https:// ginasthma.org/recommendations-for-inhaled-asthma-controller-medications/ [Accessed 18th September 2020].

51. American Lung Association, Asthma \& COPD: CoViD-19 myth busting with Dr. Juanita Mora. Available from: https://www.lung. org/blog/covid-19-myth-busting [Accessed 18th September 2020].

52. NICE Guideline, COVID-19 rapid guideline: community-based care of patients with chronic obstructive pulmonary disease (COPD). Available from: https://www.nice.org.uk/guidance/ ng168/chapter/2-Treatment-and-care-planning [Accessed 18th September 2020].

53. Morais-Almeidaa M, Aguiara R, Martin B, Ansotegui IJ, Ebisawa M, Karla Arruda L, et al. COVID-19, asthma, and biological therapies: What we need to know. World Allergy Organization Journal. 2020;13: 100126.

54. European Lung Foundation (ELF) recomandations. Available from: https://www.europeanlung.org/covid-19/covid-19-information-and-resources/covid-19-info [Accessed 19th September 2020].

55. Ministry of Health Pneumology Commission. Recommendations on the approach to respiratory diseases during the Covid-19 pandemic. Nr. 29/21; April 2020. Available from: http://www.ms.ro/ wp-content/uploads/2020/04/Recomanda\%CC\%86ri-cu-privirela-abordul-afect\% CC\%A6iunilor-respiratorii-pe-perioadapandemiei-COVID-19.pdf [Accessed 19th September 2020]. 